\title{
How Can UN Digital Policy Enable the Rights of Women?
}

\author{
Anna Maria Rada Leenders \\ University of Sofia, Sofia, Republic of Bulgara, \\ Moscow State Institute of International Relations (MGIMO University), Moscow, \\ Russian Federation \\ 凹amrada4@mail.ru
}

\begin{abstract}
In most academic discourses, United Nations (UN) programs and initiatives to promote digitalization and women's rights are studied as distinct fields. Less attention has been paid to UN efforts to promote gender equality and protect women's rights by promoting digitalization. The article addresses some of the gaps in the contemporary research of the role of modern international intergovernmental organizations in women's rights protection amidst modern technological development. The study reveals the influence of digitalization on ameliorating the position of women in modern societies and formulates the assessment of the gender gap in using the ICT technologies, as well as analyzes how UN specialized divisions act to ensure digital gender equality. The author concludes that the Sustainable Development Goals (SDGs) approved by the UN in 2015 do not pay enough attention to the importance of digitalization for ensuring the rights of women.
\end{abstract}

Keywords: women's rights, gender studies, global governance, UN, digitalization, gender gap

For citation: Leenders, A.M.R. (2022). How can UN digital policy enable the rights of women? RUDN Journal of Political Science, 24(1), 53-63. https://doi.org/10.22363/2313-1438-202224-1-53-63

\section{Как цифровая политика ООН может способствовать реализации прав женщин}

\author{
А.М.Р. Линдерс \\ Софийский университет, София, Республика Болгария, \\ Московский государственный институт международных отношений (университет) \\ Министерства иностранных дел Российской Федерации, Москва, Российская Федерация \\ 凹amrada4@mail.ru
}

Аннотация. В академической литературе программы и инициативы ООН по продвижению цифровизации и защите прав женщин обычно изучаются отдельно. Меньше внимания уделяется усилиям ООН по продвижению гендерного равенства и защите прав женщин путем

(C) Leenders A.M.R., 2022

(c) (i) This work is licensed under a Creative Commons Attribution 4.0 International License https://creativecommons.org/licenses/by/4.0/ 
продвижения цифровых технологий. В статье восполняются некоторые пробелы в современных исследованиях вклада современных международных межправительственных организаций в защиту прав женщин в современных условиях технологического развития. Выявлено влияние процессов цифровизации на улучшение положения женщин в современных обществах за счет обеспечения прав женщин. Представлена оценка проблемы гендерного разрыва в использовании ИКТ-технологий. Установлено, что в Целях устойчивого развития (ЦУР), утвержденных ООН в 2015 году, недостаточно внимания уделяется важности цифровизации для обеспечения прав женщин. Анализируются различные формы деятельности специализированных подразделений ООН, обеспечивающих цифровое гендерное равенство.

Ключевые слова: права женщин, гендерные исследования, глобальное управление, ООН, цифровизация, гендерный разрыв

Для цитирования: Leenders A.M.R. How can UN digital policy enable the rights of women? // Вестник Российского университета дружбы народов. Серия: Политология. 2022. Т. 24. № 1. C. 53-63. https://doi.org/10.22363/2313-1438-2022-24-1-53-63

\section{Introduction}

Activities for ensuring the rights of women and gender equality always reflect the characteristics of a specific historical era. In the 2000s the most important factors influencing this activity became the continuing activation of international organizations and the process of digitalization and development of Information Communication Technologies (ICT) technologies.

The leading international organizations, first of all, the United Nations (UN), stand in the vanguard of humanity's efforts to ensure the rights of women and to assist digitalization processes [Alves 2016; Arat 2015; Leenders, Grishin 2020]. As a result, these tasks intertwine and are closely connected to each other. In 2015, gender equality was proclaimed by the United Nations General Assembly (UN GA) as of one of Sustainable Development Goals (SDGs). Digitalization and digital cooperation is also one of main priorities on the UN agenda with heightened attention added in the new millennia [Girard 2020]. At the same time, digital development is considered as one of the most important facilitators and tools of implementation of women's rights at the present stage of social and human development. Along with it, processes of digitalization bring new challenges to protecting women's rights.

In 2000s, the list of traditional problems of gender equality was exacerbated with a new dimension: the digital divide. Originally, it was considered that in the process of distributing modern technologies and digitalization, the differences between men and women in gaining access to computers will only be reduced [Herr 2019]. However, one of paradoxes of the impact of digitalization on social development was the fact that the digital divide only increases. In particular, this trend is characteristic of the 2010s. Thus, at the present stage a question arises: whether ICT technologies promote overcoming the gender gap, or, on the contrary, its strengthening?

In modern scientific literature, the question: 'to what degree the activity of the international organizations in the sphere of digitalization can promote reduction of 
a gender gap in access to digital technologies and protection of women's rights,' is not studied. The purpose of this article is to assess the modern policy of the UN on use of ICT and digital development for achieving gender equality and the protection of women's rights. Taking into account that ICT enables the liberalization of the voices of women in the global dialogue and representing the position of women.

\section{The Status of Women's Rights during the Contemporary Process of Digitalization}

Women's rights remain one of the most important issues of the contemporary world [Popova, Maslova, Agapitova 2016]. The paradox is that the development of modern information technologies led to emergence of new difficulties in a question of gender equality. Unequal access to digital technologies and the Internet is substantially caused by the societal contradictions existing throughout history [Renzulli 2017].

According to research conducted in 2018, women and female children became the victims of cyberbullying 27 times more often than men [Sandler, Goetz 2020]. The aggressive behavior against women on the Internet negatively affects women's health, causing damage to women's self-respect. In addition, the results of such aggression lead women to avoid communication on the Internet that only promote the preservation of a high level of gender inequality in digital space. According to some experts, such negative effects interfere with women's access to modern digital technologies. Whereas, ICT enables women's voices to be heard and women's perspective to be included in the global debates and policy making.

In 2016, United Nations experts estimating the level of gender inequality in use of the Internet and digital technologies came to pessimistic conclusions. It was revealed that at the global scale the number of women using online technologies is some 2500 million fewer than number of men. Researches proved that during the period from 2013 to 2016 the gender gap grew from 11 to 12 percent. The greatest values of this gap (up to 31 percent) were recorded in the least developed countries. ${ }^{1}$

Gender inequality exists among people working in ICT sector in an even more pronounced way. By 2015, in every country there are fewer women in the ICT workforce at every level. In 2020 a very significant international survey about Women in Tech and Startups was conducted. According to the results received, that $70 \%$ of women working in the sphere of technologies feel they have been treated and paid differently at work owing to their gender, while only of $11 \%$ of men in the sphere feel this way. ${ }^{2}$ Most of the women working in ICT sector continue to consider that they face additional barriers and have less opportunities for successful creation of career. The results of some modern researches show that only $11 \%$ of

\footnotetext{
${ }^{1}$ ITU and UN Women announce 'EQUALS': The Global Partnership for Gender Equality in the Digital Age. URL: https://www.unwomen.org/en/news/stories/2016/9/press-release-itu-and-unwomen-announce-global-partnership-for-gender-equality-in-the-digital-age (accessed: 21.08.2021).

${ }^{2}$ Women Who Tech (2020). State of Women in Tech and Startups. URL: https://womenwhotech.com/ data-andresources/state-women-tech-and-startups (accessed: 21.08.2021).
} 
the cyber security work force is female. Among the leading positions in the industry of ICT only $24 \%$ are women.

As the ICT sector the sector of cyber security are actively developing, so low level of representation of women poses serious problems for the prospects of socialization of women. It is one of the most promising sectors of economy for successful construction. Integration of women into this sphere is an important component of integration of women into modern economy.

\section{Issues of Digitalization and Women's Rights in the Context of Sustainable Development Goals}

The $\mathrm{UN}$ is the international intergovernmental organization making the most considerable impact on development of progressive trends in various spheres of public life. Issues of digital development and digital transformation of the modern world are also subject to influence from the UN more than from any other actor of the international community [Leenders 2020].

At the present stage, the most important priority of United Nations operation and its institutes is achievement of the goals of sustainable development (SDGs). In this regard, United Nations operation in the sphere of digital development and assistance of the UN to digital development can be considered in the context of United Nations operation on achievement of SDGs [Zipoli 2019].

The most important document of the UN concerning sustainable development is the resolution of the UN General Assembly of A/70/L.1 "Transforming our world: 2030 Agenda for Sustainable Development". ${ }^{3}$ The concept of digitalization occurs in the text of the resolution only once: in Paragraph 15 it is told about need of overcoming the "digital divide". The task $5 \mathrm{~b}$ mentions ICT as the stimulating technology for expansion of the rights and opportunities of women in purpose 5 ("Gender equality"). SDG 5 contains nine targets that assume the elimination of any forms of discrimination, operation, violence against women and girls, ensuring completeness of participation and equal opportunities of women in public life, providing the equal rights and access to public resources [Kim 2017]. The most interesting Target 8 , as it enhances the appropriation and use of enabling technology, in particular information and communications technology, to promote the empowerment of women [Dhar 2018]. Nevertheless, gender digital divide perspective the text of the resolution of the UN General Assembly isn't mentioned.

It is possible to note that the weak attention to ICT and digitalization as to means of achievement of SDGs is present not only at the resolution of the UN General Assembly of 2015, but also at other documents of the UN concerning sustainable development.

However, after 2015 a situation changed: issues of digitalization were high more in United Nations operation and in work on achievement of SDGs. Active work of expert community became one of the reasons [MacPhail 2017]. During the

\footnotetext{
3 Transformation of our world: the agenda in the field of sustainable development until 2030. Resolution A/70/L.1 of the UN General Assembly, on September 25, 2015.
} 
period which is directly following adoption of the resolution of the UN General Assembly of A/70/L.1 by a number of experts were stated a critical remark and concern about excessively small attention to ICT and digitalization by consideration of prospects of achievement of SDGs in documents of the UN.

In consideration of value of digitalization for achievement of IMC there is a certain thesis, obvious to most of experts, which can be met in many reports and articles. This thesis, in our opinion, on the basis of generalization of the sources studied by us, it is possible to formulate as follows: "Technologies, especially ICT, are crucial for ensuring creativity, innovation and adaptability of modern economy: digitalization has interindustry value and is the powerful tool of economy and social development which can be used for achievement of all sustainable development goals". Most of authors meet that in the future the digital economy potentially is the most considerable and important opportunity for dynamic changes and sustainable development around the world.

In June, 2018 UN Secretary-General presented the report on prospects and problems in achievement of the Sustainable Development Goals in which questions of achievement of gender equality in the digital sphere were also reflected. This report declared that the SDGs cannot be fulfilled until SDG 5 (Gender Equality) is achieved. ${ }^{4}$

\section{Contribution of the UN Secretary-General High-level Panel on Digital Cooperation for Ensuring Gender Equality in Digital Sphere}

The High-level Panel on Digital Cooperation became one of the original institutes created within United Nations operation for achievement of bigger effect in assistance to the separate directions of social development.

High-level Panel on Digital Cooperation introduced by the United Nations Secretary General António Gutterres develops recommendations of how the international community can work together for optimizing of use of digital technologies and risk reduction. The creation of group was declared in July, 2018. In particular, the principle of a gender variety was put in the basis of work of group. 22 persons were a part of group (including cochairmen and heads of the secretariat). The representation by certain sectors was distributed as follows: 5 people represented public authorities (at the level of the minister, the following states: India, the UAE, Norway, Botswana, Switzerland), 7 people - business (including, presenting to IT technology), 10 people - the public and research organizations [Prestes 2019]. The representation from the countries was distributed as follows: 3 persons presented to the USA, 19 more countries received on 1 representative (including Russia).

The group was created for the nine-month period after which it had to submit the report containing recommendations. The report had to increase the awareness of politicians and the general public about the reformative influence of digital

\footnotetext{
${ }^{4}$ Progress towards the Sustainable Development Goals: report of the UN Secretary-General, E/2018/64, 2018.
} 
technologies on society and economy. In the report ways of expansion of digital cooperation by identification of gaps in the existing policy, researches and information had to be formulated. It was established that the report has to contain recommendations for the maximum use of potential of digital technologies, in particular, for realization of the 2030 Agenda for Sustainable Development. It was established that all interested parties, the group had to pay special attention to ensuring assistance to participation of youth and women in the digital sphere.

The group finished the discussions and in June, 2019 submitted to the UN Secretary General the report of "The Age of Digital Interdependence". In this report the word "gender" isn't used. However, this report also made a contribution to drawing attention to the problem of digital inequality of women. In particular, women are mentioned in a number of social groups whose representation in the World Wide Web needs to be raised. Concerning recommendation $1 \mathrm{C}$ the report contained an appeal to civil society and authorities to take concrete strategic measures for ensuring full familiarizing with digital technologies and digital equality for women and other social groups which are traditionally considered as marginalized. High-level Panel's Report contained specific proposals and measures for advance on the way of achievement of digital gender equality, but his contribution consists in fixing of value of this purpose.

For the purpose of follow-up process of implementation of the report in 2019 8 virtual Roundtable groups were formed. Participants of these groups were divided into categories "Champions" and "Key Constituent".

The algorithm of activity of virtual Roundtable groups allowed to be shown to the main types of subjects [Kleinwächter, Kettemann, Senges 2019]. In particular, the structure of "Champions" mainly included only public authorities of the national states and specialized structures and the UN agencies. An exception kept the Microsoft and iSPIRT companies and the international public organization Access Now. The structure of category "Key Constituent" was much more numerous and various; their number several times exceeded number of "champions" and in each direction them was on average from 30 to 40 . Though among this category also considerable share was occupied by the governments of the national states, but also the share of business structures (especially from information technology), the research organizations and institutes of civil society was big. It is possible to note that among the persons which had the status of full-fledged participants of these discussions the participation of individual faces per se wasn't provided (for example, from among world famous experts or scientists); such right was granted only to the organizations.

The expediency of division of participants into categories "Champions" and "Key Constituent" consisted in division of roles at discussion of the corresponding directions. The organizations representing the Champions group prepared the conclusion on the basis of studying the report of the High-level Panel on Digital Cooperation. The organizations which are among "Key Constituent" studied after that this conclusion and prepared the response in which were reflected as comments on the main report, and in relation to the conclusion of "Champions". It is possible 
to recognize this operation algorithm as rather effective as it provided higher degree of an internal discussion and dialogue at discussion of the possible directions and measures for achievement of objectives. Possibly, and the distinction of structure of "Champions" and "Key Constituent" could also have effect on contents of final offers: in the first case offers from the point of view of the national states and the UN agencies were presented in the conclusion, in preparation of the alternative conclusion participated in the second case, besides subjects such, also business structures and NPO that allowed to see a problem from a different perspective

On December 6, 2019 virtual Roundtable groups presented results of the discussion of the report within the set directions two of the eight virtual Roundtable groups; in the Roundtable's recommendations the issue of the gender gap was mentioned. The High-level Panel Follow-up Roundtable 1A ("Global Connectivity") in its recommendation announced that the gender gap in internet access is increasing in many parts of the world. In the High-level Panel Follow-up Roundtable 1C ("Digital Inclusion") participants expressed their concern about the need to increase knowledge about that how the gender gaps arises in the use of digital technology, and to develop such knowledge as to how this problem can be eradicated. Gender gaps were set as a priority area for consideration in digital inclusion. The participants in the groups were convinces that the digital divide between women and must be bridged.

It is possible to make the assumptions that participants in the virtual Roundtable groups did not offer new mechanisms or approaches to a solution of the problem of overcoming the gender gap in internet access, but they drew additional attention to him more likely and legitimized the importance of the solution of this problem.

\section{The Issue of the Gender Divide in the UN Secretary-General's Roadmap for Digital Cooperation}

The UN Secretary-General's Roadmap for Digital Cooperation is one of the new instruments of the United Nations in the sphere of governing digital development: setting norms and providing platforms to coordinate policy and regulation. ${ }^{5}$ This document also raises the questions of gender equality and women's rights. The UN Secretary-General's Roadmap for Digital is presented on the United Nations General Assembly in May, 2020.

The gender perspective is mentioned in the text of this document 10 times. The gender gap is called a striking example of the existing digital inequality. It is noted that in two of each three countries of the world more men, than women use the Internet. The road map denies the optimistic assessment of a relative gender gap existing a few years ago in use by digital technologies. In the text of the document it is said that the gender gap grows in use by the Internet, but it isn't reduced: in 2019 he made 17 percent, and in the least developed countries it is even more, notably 43 percent $\%$.

\footnotetext{
${ }^{5}$ Road map for digital cooperation: implementation of the recommendations of the High-level Panel on Digital Cooperation. Report of the UN Secretary-General, A/74/821, 29 May 2020.
} 
The Secretary-General's Roadmap pronounced the creation in 2021 of the multilateral coalition for taking measures in the field of innovations and technologies for the benefit of gender equality. The extreme importance of ensuring accounting of gender specifics at acceptance of any measures in the field of digital cooperation and digital technologies was proclaimed. For the most effective system of decision-making The Secretary-General's Roadmap suggested to recognize that degree of vulnerability in a context of digitalization depends on gender accessory.

It is possible to assume, as this document not so much assumes concrete measures of overcoming gender inequality how many postulates importance of this problem and proclaims the need to overcome the problem.

\section{Other Forms of Activity of Specialized Divisions of the UN of Ensuring Digital Gender Equality}

At an arsenal of modern means of the UN there are some other forms of activity directed to achievement of progress in questions of protection of women's rights, gender equality and digitalization.

In 2016, the year began with a the form of gender governance: the coalition of programs "EQUALS" (the Global Partnership for Gender Equality in the Digital Age). This project was launched in September 2016 by International Telecommunication Union (ITU) and UN Women. ${ }^{6}$

ITU Secretary-General Houlin Zhao announced that "It's time to make the world more equal ... EQUALS, Global Partnership for Gender Equality in the Digital Age, program where we will collaborate with partners to generate an unstoppable global movement where women and girls are equal participants in the digital technology revolution. Big challenges like these require better data, just as global problems require global action". ${ }^{7}$

Phumzile Mlambo-Ngcuka, Executive Director of UN Women, also highlighted the foundational role of the digitalization project: "The information society is incomplete without the inclusion, contribution and leadership of women and girls ... They must have access to ICTs, and we must foster their capabilities to use the technology. This is central to the realization of women's rights at all levels and can be a real driver of accelerated progress towards the achievement of Agenda 2030" [Gilleri 2020].

EQUALS is a project that aims to achieve the Sustainable Development Goal 5b: "Enhance the use of enabling technology, in particular information and communications technology (ICTs), to promote the empowerment of women". To realize the goals of the program the website (https://www.equalsintech.org) was created. Within this project three main activities are emphasized:

\footnotetext{
${ }^{6}$ Perceptions of Power: Championing Female Leadership in Tech: An EQUALS report by GSMA. London: GSMA, 2020.

7 ITU and UN Women announce 'EQUALS': The Global Partnership for Gender Equality in the Digital Age. URL: https://www.unwomen.org/en/news/stories/2016/9/press-release-itu-and-unwomen-announce-global-partnership-for-gender-equality-in-the-digital-age (accessed: 21.08.2021).
} 
ACCESS (Achieve equal access to contemporary digital technologies)

SKILLS (Empower women with skills to become ICT creators)

LEADERS (Promote women as ICT leaders)

The International Telecommunication Union (ITU) and UN Women are the main specialized UN agencies dealing with issues of digital development and women's rights, respectively. Thus, the launch of this joint project with participation of these two organizations was a highly challenging endeavor. These organizations systematically magnetize other participants to implement the joint program for ensuring gender digital equality. In 2016 entrepreneur and founder of Honest Dollar, William Hurley, was involved with the project. In 2020, Oslo Metropolitan University together with associates from GSMA, ITC, and UNU participated in EQUALS to prepare the analytical report on the global status of the issue: overcoming the digital inequality of women. In the report prepared for the EQUALS project a number of measures and recommendations about achieving gender equality were developed. It was proposed that fostering gender inclusion in the ICT sector to ensure gender balance in decision-making positions (for instance, the boards of directors).

In 2020 the UN Secretary-General announced the launch of the project: "A Global Acceleration Plan for Gender Equality". France, Mexico and UN Women, took a leading part in realizing this project. This project was launched at the Paris Forum and consists of six Action Coalitions: innovative multi-stakeholder partnerships involving national governments, international governmental and nongovernmental organizations, civil society and youth organizations.

The ITU in 2020 began a new project that was caused by the new challenges of a pandemic of COVID-19. The webinar "Empowering Women in Cybersecurity" organized by CyberDrill took place in 2020 addressed the communication of women around the world in the ICT sector. Participants discussed obstacles in the field of cyber security which women in different countries were dealing with, and ways of overcoming the constraints women face. Conclusions were drawn on the need to develop new forms of communication between the women working in the sphere of digital technologies, further transformation of culture and to change stereotypes of thinking, development of programs for advancing female leaders in this sphere. The criticism of the myth that the sphere of cyber security has to be a closed professional sphere in which only experts with a long experience have to work became one of the most interesting results of this action. According to participants of the webinar, this conclusion is not true and also interferes with the integration of women into this sphere like an entry barrier to new ICT professionals. In total three main obstacles were revealed: lack of mentors, absence of this sphere of professional activity of female role models of successful career, gender stereotypes of and bias.

One of the aims of the webinar is the program "Empowering Women in Cybersecurity Global Mentorship", that the ITU realized together with the Forum of Incident Response and Security Teams (FIRST) and EQUALS to fill a lack of mentorship of the women working in ICT sector. The program, launched on 
International Women's Day, the 8th March 2021, program was focused, first of all, on the countries of Asia and Africa. The first round of the program proceeded from March to August 2021, the future editions of the program have to cover a number of the new countries.

\section{Conclusion}

At the present stage the active work of the international community for protecting women's rights and overcoming the gender gap in the digital sphere is only in its initial stage. The United Nations programs in this sphere of regulation differ in the level of commitment, initiative and mobilization of various resources [McQuigg 2018]. The United Nations widely applies a variety of forms of working programs, including creating new forms that allow achieving a synergy of efforts of the international organizations, businesses, civil society, as well as in other directions of United Nations' work.

The activity of the United Nations and its divisions in the sphere of ensuring gender equality and overcoming digital inequality is the work focused directly on society, human beings as planetary inhabitants deserving equal rights and opportunities, has been known to bypasses the national states as intermediaries. However, this line work is characteristic of most of the modern international organizations in various spheres of public life and most member states of the United Nations seek to respect women's rights and even to empower women. The United Nations implements programs of social development, directly addressing recipients of the help that try to influence the process by influencing the policy of national states. This trend corresponds to a current trend of development of global governance of digital women's rights. The United Nations should attract the capacity of national states more, and involve separate government structures to implement specific programs (for example, to the EQUALS program) more systematically and consistently. It is possible to assume that the effectiveness of efforts of the UN could be higher if United Nations would use the capacity of the national states more actively, where as nations state themselves should initiate progream to cooperate with the United nations to the norms set by the international community for digital women's rights.

Received / Поступила в редакцию: 22.08.2021

Revised / Доработана после рецензирования: 12.10.2021

Accepted / Принята к публикации: 15.11.2021

\section{References}

Alves, J.E.D. (2016). Desafios da equidade de gênero no século XXI. Revista Estudos Feministas, 24(2), 629-638. https://doi.org/10.1590/1805-9584-2016v24n2p629

Arat, Z.F.K. (2015). Feminisms, Women's Rights, and the UN: Would Achieving Gender Equality Empower Women? American Political Science Review, 109(4), 674-689. https://doi.org/10.1017/s0003055415000386

Dhar, S. (2018). Gender and Sustainable Development Goals (SDGs). Indian Journal of Gender Studies, 25(1), 47-78. https://doi.org/10.1177/0971521517738451 
Gilleri, G. (2020). ‘How are you actually doing, ladies?’ Indicators of gender equality through the lens of the UN Committee on the Elimination of Discrimination against Women. International Journal of Human Rights, 24(8), 1218-1246. https://doi.org/10.1080/13642987.2020.1717474

Girard, M. (2020). We Need Standards for Digital Cooperation to Occur. IEEE Technology and Society Magazine, 39(2), 68-74. https://doi.org/10.1109/MTS.2020.2991501

Herr, R.S. (2019). Women's Rights as Human Rights and Cultural Imperialism. Feminist Formations, 31(3), 118-142. https://doi.org/10.1353/ff.2019.0033

Kim, E.M. (2017). Gender and the Sustainable Development Goals. Global Social Policy, 17(2), 239-244. https://doi.org/10.1177/1468018117703444

Kleinwächter, W., Kettemann, M.C., \& Senges, M. (Eds.). (2019). Towards a Global Framework for Cyber Peace and Digital Cooperation: An Agenda for the 2020s. Hamburg: Verlag HansBredow-Institut.

Leenders, A.M. (2020). International relations and technological conditionality. The Caspian Region: Politics, Economics, Culture, 1, 96-104. https://doi.org/10.21672/1818-510X-202062-1-096-104 (In Russian).

Leenders, A.M., \& Grishin, N. (2020). United Nations institutions for the development of digital cooperation. Political Expertise: POLITEX, 16(4), 493-504. https://doi.org/10.21638/spbu23.2020.405 (In Russian).

MacPhail, F. (2017). Progress of the world's women 2015-2016: transforming economies, realizing rights, by UN Women. Canadian Journal of Development Studies/Revue canadienne d'études du développement, 38(2), 1-3. https://doi.org/10.1080/02255189.2017.1303366

McQuigg, R. (2018). Is it time for an UN treaty on violence against women? The International Journal of Human Rights, 22(3), 305-324. https://doi.org/10.1080/13642987.2017.1359552

Popova, O.V., Maslova, A.E., \& Agapitova, M.I. (2016). Problems of reproductive health of women and abortions in programs of the Russian political parties. The Woman in the Russian society, 4(81), 72-84. https://doi.org/10.21064/WinRS.2016.4.6 (In Russian).

Prestes, E. (2019). An Overview of the United Nations High-Level Panel on Digital Cooperation. IEEE Robotics \& Automation Magazine, 26(1), 103-104. https://doi.org/10.1109/MRA.2019.2891183

Renzulli, I. (2017). 'Women and peace': A human rights strategy for the women, peace and security agenda. Netherlands Quarterly of Human Rights, 35(4), 210-229. https://doi.org/10.1177/0924051917737912

Sandler, J., \& Goetz, A.M. (2020). Can the United Nations deliver a feminist future? Gender \& Development, 28(2), 239-263. https://doi.org/10.1080/13552074.2020.1753432

Zipoli, D. (2019). NHRI Engagement with UN Human Rights Treaty Bodies: A Goal-based Approach. Nordic Journal of Human Rights, 37(3), 259-280. https://doi.org/10.1080/18918131.2019.1682241

\begin{abstract}
About the author:
Anna Maria Rada Leenders - MSc in Political Science of the Columbia University, lecturer of the University of Sofia, postgraduate of the MGIMO University (e-mail: amrada4@mail.ru) (ORCID: 0000-0001-7356-1456)
\end{abstract}

\title{
Сведения об авторе:
}

Линдерс Анна Мария Рада - магистр политологии Колумбийского университета, преподаватель Софийского университета, аспирант МГИМО МИД России (e-mail: amrada4@mail.ru) (ORCID: 0000-0001-7356-1456) 